\title{
Glucose intolerance in chronic renal failure
}

\section{-A study from the viewpoint of insulin receptor-}

\author{
Yoshio Nakamura, M. D., Hitoshi Nishioka, M. D., Takahiro Kanatsuna, M. D., \\ Motoharu Kondo, M. D., Akio Fujisawa, M. D.*, Tsuguo Shikata, M. D.* \\ First Department of Internal Medicine, Kyoto Prefectural University of Medicine. \\ Higashiwakidai Hospital*
}

(昭和 58 年 8 月 16 日受付)

key words : glucose intolerance, chronic renal failure, insulin receptor, hemodialysis

$\langle$ Abstract〉

In order to clarify the pathogenesis of glucose intolerance in chronic renal failure, we investigated it from the viewpoint of insulin receptor. IV-GTT $(0.5 \mathrm{~g} / \mathrm{kg})$ was performed in 10 undialyzed and 12 dialyzed patients with chronic renal failure and 6 normal subjects, and their insulin receptors were examined. $\Sigma \mid R I$ (the sum of IRI during IV-GTT) in the undialyzed group was $445 \pm 78 \mu \mathrm{U} / \mathrm{m} l$, which was significantly higher than that $(260 \pm 38 \mu \mathrm{U} / \mathrm{m} l)$ in the normal group. The $\mathrm{K}$ value (glucose disappearance rate) in the undialyzed group was $1.32 \pm 0.30$, which was significantly lower than that $(1.92 \pm 0.25)$ in the normal group and that $(1.82 \pm 0.34)$ in the dialyzed group. No significant difference in $\mathrm{K}$ value was recognized between the normal and dialyzed groups.

The specific binding of ${ }^{125}$-insulin to erythrocytes $\left(2.4 \times 10^{9} \mathrm{cells} / \mathrm{m} l\right)$ in the undialyzed group was $3.99 \pm 0$. $76 \%$ which was significantly lower than that $(5.50 \pm 0.69 \%)$ in the normal group. However, no significant difference was observed between the normal and dialyzed groups. When competition data for the three groups were subjected to Scatchard analysis, the difference in binding to erythrocytes appeared to be due to the difference in receptor concentration rather than receptor affinity (receptor concentration: 42, 58, and 64 sites/erythrocyte in the undialyzed, dialyzed, and normal groups, respectively). In the dialyzed group, the correlation coefficients between the specific binding of ${ }^{125} \mathrm{I}$-insulin and $\mathrm{K}$ value $(r=0.542)$ were higher than those between the binding and fasting IRI, $\Sigma I R I$ ( $r=-0.381,-0.272$ ).

From these results, it is suggested that glucose intolerance in chronic renal failure is founded on a decrease in insulin receptor concentration, and that hemodialysis improves this glucose intolerance through increased sensitivity to insulin action in the peripheral tissue with accompanying normalization of the insulin receptors.

\section{腎不全における耐糖能異常の成因についてーインスリン受容体からの検討一}

\section{中村 義雄, 西岡 均, 金綱 隆弘, 近藤 元治, 藤沢 明生 ${ }^{*}$, 四方 統男*}

京都府立医科大学第 1 内科, 東脇台病院 ${ }^{*}$

慢性腎不全に耐糖能異常が存在することはよく知られているが, その成因については不明な点が少なくない.イン スリン抵抗性もその一因と考えられているが，この点をさらに明らかにするためにインスリン受容体の面から検討し た. 未透析腎不全患者 10 名, 透析患者 12 名および正常者 6 名を対象に赤血球のインスリン受容体を検討し, $0.5 \mathrm{~g} / \mathrm{kg}$

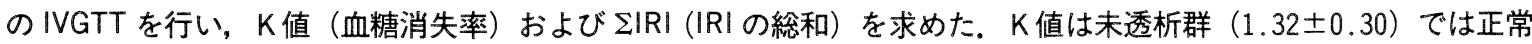

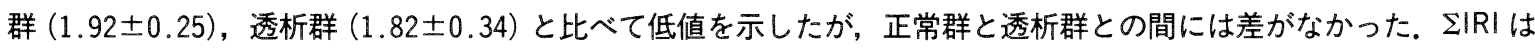
末透析群 $(445 \pm 78 \mu \mathrm{U} / \mathrm{m} l)$, 透析群 $(420 \pm 80 \mu \mathrm{U} / \mathrm{m} l)$ は正常群 $(260 \pm 38 \mu \mathrm{U} / \mathrm{m} l)$ と比べて高値を示したが, 未

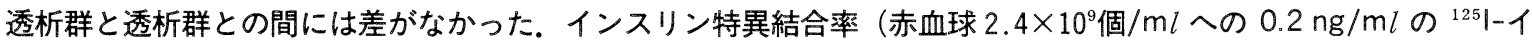

中村 義雄 京都府立医科大学第 1 内科

于 602 京都市上京区河原町通広小路上ル梶井町 465 （075-251-5111） 


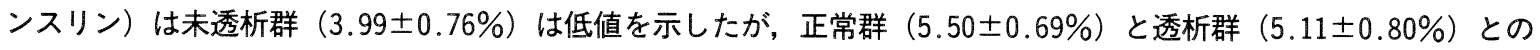
間には有意差がなかった. Scatchard 解析より, 未透析群におけるインスリン特異結合率の低下はインスリン受容体 数の減少によるものと思われた（正常群 64 個/cell ; 透析群 58 個/cell ; 未透析群 45 個/cell).

さらに，耐糖能異常とインスリン受容体との関係を明らかにするために，インスリン特異結合率とK 值および空腹 時 IRI, $\Sigma \mid R I$ との関係をみたが, 透析群において特異結合率とK 值との間に正の相関を認めた. このことより, 未透 析腎不全患者の耐糖能異常はインスリン受容体数の低下によるものと思われ, 透析療法はインスリン受容体レベルで の改善により耐糖能障害を正常化させるものと思われた。

\section{Introduction}

The presence of impaired glucose metabolism in patients with chronic renal failure has been widely recognized $^{1,2,3)}$. However, the exact etiology of such glucose intolerance remains unclear. It is suggested that insulin resistance may represent one of its etiologies based on the finding of a delayed, diminished fall in blood glucose concentration in spite of a high serum insulin level during intravenous glucose injection ${ }^{1)}$. In this connection, Gambhir et al. ${ }^{4)}$ reported a decreased insulin receptor concentration in the erythrocytes of uremic patients. However, when the insulin receptors of uremic patients are investigated, the relationship between glucose intolerance and the insulin receptors should also be considered in the same patients.

In the present study, we examined the glucose metabolism of undialyzed patients with chronic renal failure and their insulin receptors, and furthermore investigated the effect of hemodialysis on their glucose intolerance.

\section{Subjects and Methods}

10 undialyzed uremic patients aged from 25-48 years, and 12 patients on chronic hemodialysis for more than two years with ages ranging from 29-47 years, were studied. The clinical profile of these patients is summarized in Table 1. 6 age-matched, healthy men and women were selected as controls. All of them were non-obese, without past and family histories of diabetes. After an over night fast, about $12 \mathrm{~m} l$ of blood was collected in a tube containing sodium heparin for insulin receptor assay. An intravenous glucose tolerance test (IV-GTT) was then carried out. Glucose was administered intravenously at a dose of $0.5 \mathrm{~g} / \mathrm{kg}$ body weight and blood was obtained before and at 10,20,30,60,90, and $120 \mathrm{~min}$ after termination of the glucose injection for measurement of the blood glucose and serum insulin concentrations.

Blood glucose was measured by the glucose-oxidase method and serum insulin by radioimmunoassay using a double-antibody method ${ }^{5}$. The glucose disappearance rate ( $\mathrm{K}$ value), which was expressed as the degree of glucose intolerance, was calculated according to the method described by Lundbaek ${ }^{6}$. $\Sigma$ IRI was the sum of the IRI at $0,10,20,30,60,90$, and $120 \mathrm{~min}$.

Insulin receptor assay in erythrocytes was performed by a modification of the method of Gambhir et al. ${ }^{77}$. The cell pellet was suspended in 2 vols of physiological saline, layered over a mixture of Ficoll-hypaque and centrifuged at $400 \mathrm{G}$ for $15 \mathrm{~min}$ at room temperature. This process was repeated twice to minimize contamination

\begin{tabular}{l|c|c|c|c|c|c|c|c|c}
\hline & Number & $\begin{array}{c}\text { Age } \\
\mathrm{yr}\end{array}$ & $\%$ IBW & $\begin{array}{c}\mathrm{BUN} \\
\mathrm{mg} / \mathrm{d} l\end{array}$ & $\begin{array}{c}\mathrm{Cr} \\
\mathrm{mg} / \mathrm{d} l\end{array}$ & $\begin{array}{c}\mathrm{Ca}+ \\
\mathrm{mEq} / l\end{array}$ & $\begin{array}{c}\mathrm{Ht} \\
\%\end{array}$ & $\begin{array}{c}\mathrm{FBG} \\
\mathrm{mg} / \mathrm{d} l\end{array}$ & $\begin{array}{c}\text { IRI } \\
\mu \mathrm{U} / \mathrm{m} l\end{array}$ \\
\hline $\begin{array}{c}\text { renal failure } \\
\text { (Undialyzed) }\end{array}$ & 10 & $\begin{array}{c}39 \\
25 \sim 48\end{array}$ & $\begin{array}{c}93 \\
81 \sim 108\end{array}$ & $\begin{array}{c}86 \\
51 \sim 114\end{array}$ & $\begin{array}{c}8.9 \\
3.9 \sim 10.6\end{array}$ & $\begin{array}{c}4.2 \\
3.8 \sim 4.9\end{array}$ & $\begin{array}{c}29 \\
24 \sim 39\end{array}$ & $\begin{array}{c}91 \\
76 \sim 111\end{array}$ & $\begin{array}{c}21 \\
14 \sim 36\end{array}$ \\
\hline $\begin{array}{l}\text { renal failure } \\
\text { Dialyzed) }\end{array}$ & 12 & $\begin{array}{c}43 \\
29 \sim 47\end{array}$ & $\begin{array}{c}104 \\
92 \sim 106\end{array}$ & $\begin{array}{c}72 \\
64 \sim 88\end{array}$ & $\begin{array}{c}8.7 \\
7.0 \sim 12.4\end{array}$ & $\begin{array}{c}4.9 \\
4.2 \sim 5.3\end{array}$ & $\begin{array}{c}24 \\
16 \sim 37\end{array}$ & $\begin{array}{c}84 \\
72 \sim 108\end{array}$ & $\begin{array}{c}24 \\
10 \sim 32\end{array}$ \\
\hline normal & 6 & $\begin{array}{c}35 \\
30 \sim 47\end{array}$ & $\begin{array}{c}97 \\
88 \sim 118\end{array}$ & $\begin{array}{c}18 \\
16 \sim 24\end{array}$ & $\begin{array}{c}1.3 \\
0.6 \sim 1.7\end{array}$ & $\begin{array}{c}5.1 \\
4.8 \sim 5.3\end{array}$ & $\begin{array}{c}43 \\
38 \sim 49\end{array}$ & $\begin{array}{c}87 \\
67 \sim 98\end{array}$ & $\begin{array}{c}13 \\
9 \sim 19\end{array}$ \\
\hline
\end{tabular}



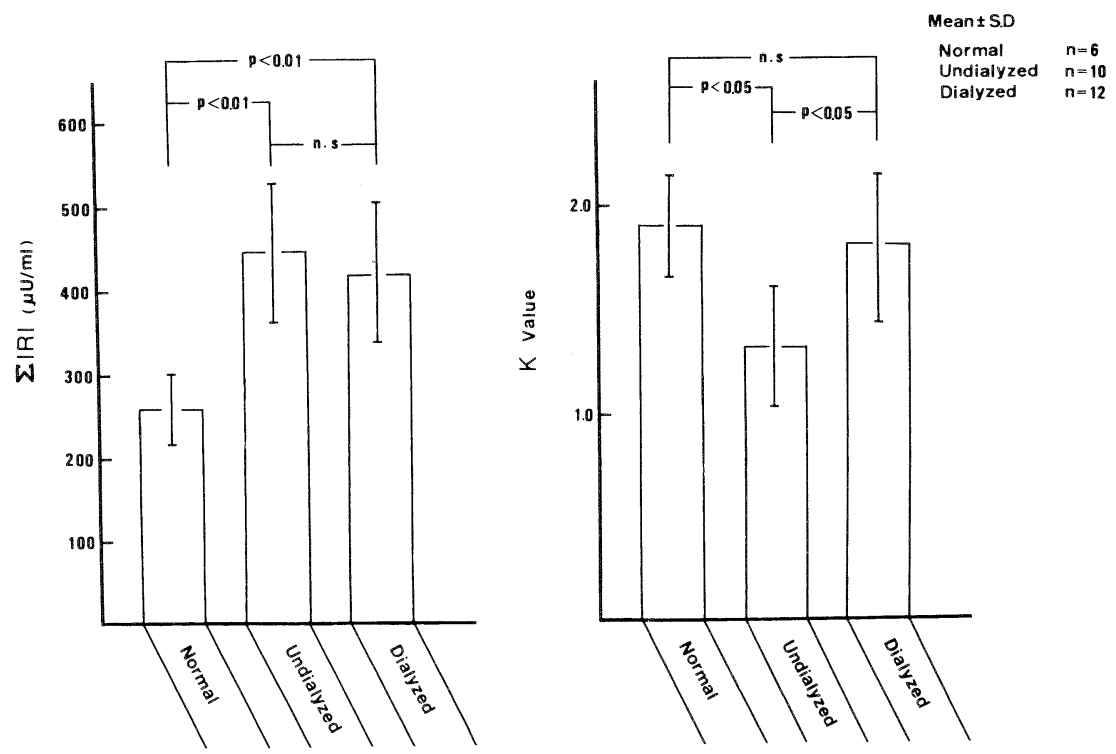

Figure $1 \quad \Sigma I R I$ and $\mathrm{K}$ value in undialyzed, dialyzed and normal groups

from leucocytes, especially mononuclear cells. The resultant erythrocyte pellet was washed three times with Tris -HEPES buffer (50 mM Tris, $50 \mathrm{mM}$ HEPES, $50 \mathrm{mM} \mathrm{NaCl}, 10 \mathrm{mM} \mathrm{MgSO}_{4}, 5 \mathrm{mM} \mathrm{KCl}, 10 \mathrm{mM} \mathrm{CaCl}_{2}, 2 \mathrm{mM}$ EDTA, $10 \mathrm{mM}$ glucose, $\mathrm{pH} 8.0$ ) containing $1 \%$ bovine serum albumin. The erythrocytes so obtained were resuspended in Tris-HEPES buffer to give about $3.0 \times 10^{9}$ cells $/ \mathrm{ml} .{ }^{125}$ labeled insulin was prepared with chloramine $\mathrm{T}$ according to the method of Hunter et $\mathrm{al}^{8}{ }^{8}$. $400 \mu l$ of the erythrocyte suspension and $50 \mu l$ of porcine monocomponent insulin (final concentration, $0.5-200 \mathrm{ng} / \mathrm{m} l$ ) and $50 \mu l$ of ${ }^{125} \mathrm{I}$-insulin (final concentration, $0.2 \mathrm{ng}$ / $\mathrm{m} l$ ) were incubated in a $15^{\circ} \mathrm{C}$ water-bath for $210 \mathrm{~min}$. After the incubation, duplicate $100 \mu l$ aliquots of the incubation mixture were transferred to prechilled plastic tubes containing $100 \mu l$ of dibutylphthalate and $200 \mu l$ of assay buffer. The microfuge tubes were then centrifuged for $150 \mathrm{sec}$ in a Beckman Microfuge and the radioactivity in the cell pellets was determined. The insulin binding was expressed as the cell-associated ${ }^{125} \mathrm{I}$ -insulin subtraction of nonspecific binding, determined in the presence of excess $\left(10^{5} \mathrm{ng}\right)$ unlabeled insulin. The degradation of the ${ }^{125} \mathrm{I}$-insulin during the binding assay, as determined by the TCA precipitation method, amounted to less than $5 \%$.

\section{Results}

The fasting blood glucose level in undialyzed uremic patients was $91 \pm 10 \mathrm{mg} / \mathrm{d} l$, that in dialyzed patients was $84 \pm 8 \mathrm{mg} / \mathrm{d} l$, and that in normal persons was $87 \pm 9 \mathrm{mg} / \mathrm{d} l$. There was no significant difference among these three groups. The $\Sigma$ IRI value in the undialyzed group was $445 \pm 78 \mu \mathrm{U} / \mathrm{m} l$, which was significantly higher than that $(260 \pm 38 \mu \mathrm{U} / \mathrm{m} l)$ in the normal group $(\mathrm{P}<0.01)$. However, no significant difference was recognized between the undialyzed group and dialyzed group $(420 \pm 80 \mu \mathrm{U} / \mathrm{m} \ell)$. In spite of the high $\Sigma$ IRI level, the $\mathrm{K}$ value in the undialyzed group was $1.32 \pm 0.30$ which was significantly lower than that $(1.92 \pm 0.25)$ in the normal group and that $(1.82 \pm 0.34)$ in the dialyzed group $(\mathrm{P}<0.05)$ (Figure 1$)$.

The insulin fraction specifically bound to erythrocytes (bound/free insulin) in normal subjects was $5.50 \pm 0$. $69 \%$ at a tracer concentration of insulin $(0.2 \mathrm{ng} / \mathrm{m} l)$. In the undialyzed and dialyzed groups, the values ranged widely from 2.21 to $5.28 \%(3.99 \pm 0.76 \%)$ and from 3.62 to $6.51 \%(5.11 \pm 0.80 \%)$, respectively. The value in the undialyzed group was significantly lower than that in the normal group $(\mathrm{P}<0.01)$. However, no significant 
change in specific ${ }^{125}$ I-insulin binding was recognized between the dialyzed and normal groups (Figure 2). When competition data for the three groups were subjected to Scatchard analysis ${ }^{9}$, the plots were curvilinear and parallel to each other. It seems likely therefore that the difference in binding to each of the erythrocytes from the three groups was due to a difference in receptor concentration rather than receptor affinity. The mean concentrations of insulin receptor, obtained by extrapolating the curves to their points of intersection on the abscissa, were 45, 58, and 64 sites/erythrocyte for the undialyzed, dialyzed and normal groups, respectively (Figure 3).

Correlation coefficients were also calculated between the binding and fasting IRI or $\Sigma$ IRI as well as between the binding and $\mathrm{K}$ value. In the undialyzed group, there was no significant correlation between the binding and other parameters. On the other hand, in the dialyzed group, a significant correlation was found between the binding and $\mathrm{K}$ value $(\mathrm{r}=0.542, \mathrm{P}<0.05)$. However, the values for the coefficients of fasting IRI and $\Sigma$ IRI were lower than that between the binding and $\mathrm{K}$ value $(\mathrm{r}=-0.381,-0.272$, respectively) (Table 2$)$.

Discussion

Our data indicate a high incidence of abnormal glucose tolerance in undialyzed patients with chronic renal failure and that hemodialysis can improve such glucose intolerance. These results are in agreement with the reports of previous investigators ${ }^{1,10,11}$. The oral glucose tolerance test (OGTT) is usually applied in demonstrating abnormalities of glucose metabolism. However, OGTT may be affected by abnormalities of glucose absorption. Uremic patients frequently have gastrointestinal diseases. Therefore, it is not adequate to apply OGTT for identifying glucose intolerance in uremic patients. For this reason, they were subjected to IV-GTT this time.

Concerning the finding that in spite of a high insulin level during IV-GTT, glucose intolerance is frequently present in undialyzed uremic patients, insensitivity to the action of insulin in the peripheral tissue is suggested. Hyperglucagonemia, elevated growth hormone levels ${ }^{12)}$ and humoral factors ${ }^{1)}$ are considered to be involved in the pathogenesis of insulin resistance in chronic renal failure. Since it is generally accepted that binding of insulin to specific receptors located on the plasma membranes of target tissue cells represents the initial step in its biological effect, it is necessary to consider such insulin resistance from the viewpoint of the insulin receptors. Although the main target organs of insulin action are the liver, muscle and adipose tissue, it is difficult to apply them clinically for insulin receptor assay. Despite the possibility of anemia, since a little blood is sufficient to isolate adequate erythrocytes for insulin receptor studies, we employed erythrocytes from uremic patients.

When discussing insulin receptors, the ${ }^{125} \mathrm{I}$-insulin binding is generally regarded as reflecting the insulin receptor since a second messenger of insulin is unknown ${ }^{13)}$. As shown in Figure 2, the ${ }^{125} \mathrm{I}$-insulin specific binding in the undialyzed group was significantly lower than that in the normal group. Scatchard analysis of the binding curves revealed that the change in insulin binding to erythrocytes was associated with a decrease in the insulin receptor concentration in undialyzed patients. Regarding the mechanism of this decrease in insulin receptor, there have been many reports supporting "down regulation"; that is, insulin receptors are regulated by the insulin concentration itself ${ }^{14,15)}$. However, it seems unlikely that the decrease in insulin binding in the undialyzed patients was simply a result of their hyperinsulinemia. Because, the insulin binding of dialyzed patients increased to the level of that of normals without a remarkable change in serum insulin level. The possibility exists therefore of the presence of other factors affecting the insulin receptor. Abnormality of humoral factors is well recognized in chronic renal failure. Furthermore, since it is reported to take more than several months for the improvement of glucose intolerance by hemodialysis ${ }^{11}$, we assume that this factor may be a "middle molecular weight substance" which is not easily dialyzed with usual hemodialysis.

Examination of the relationship betwen the binding and other parameters such as fasting IRI and IIRI, revealed a correlation with the $\mathrm{K}$ value rather than fasting IRI or $\Sigma$ IRI. It seems possible therefore that hemodialysis may cause the insulin receptor concentration to normalize and improve the glucose intolerance through an increased sensitivity to insulin action in the peripheral tissue. 


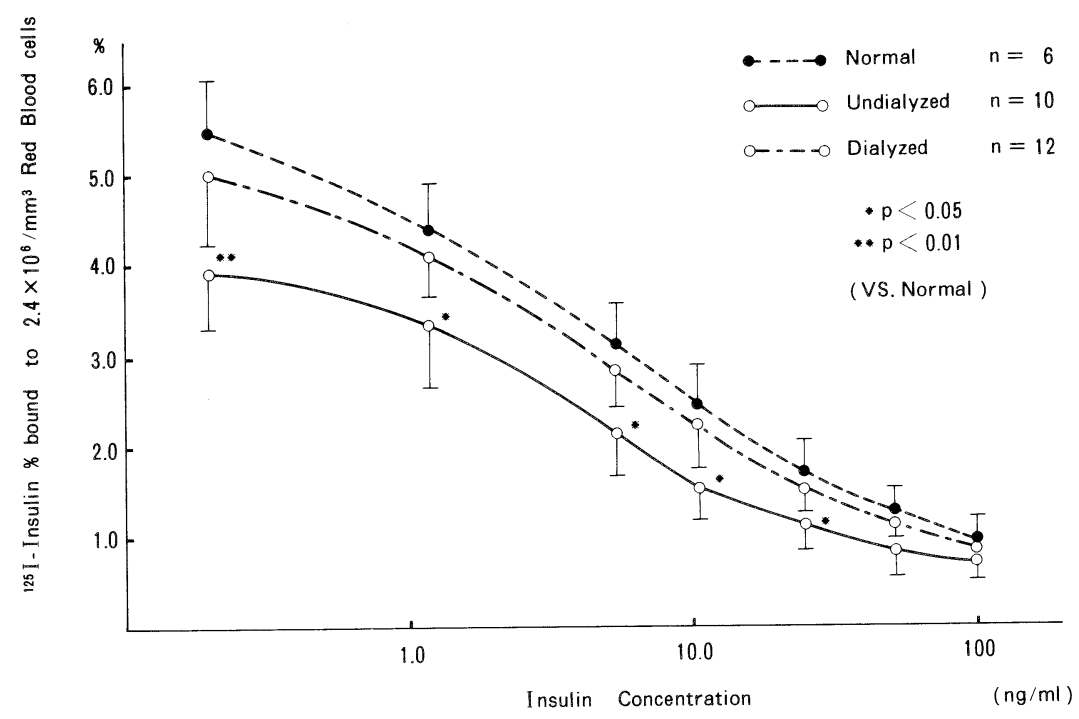

Figure 2 Specific ${ }^{125}$ I-insulin binding (\%) to erythrocytes in undialyzed, dialyzed and normal groups

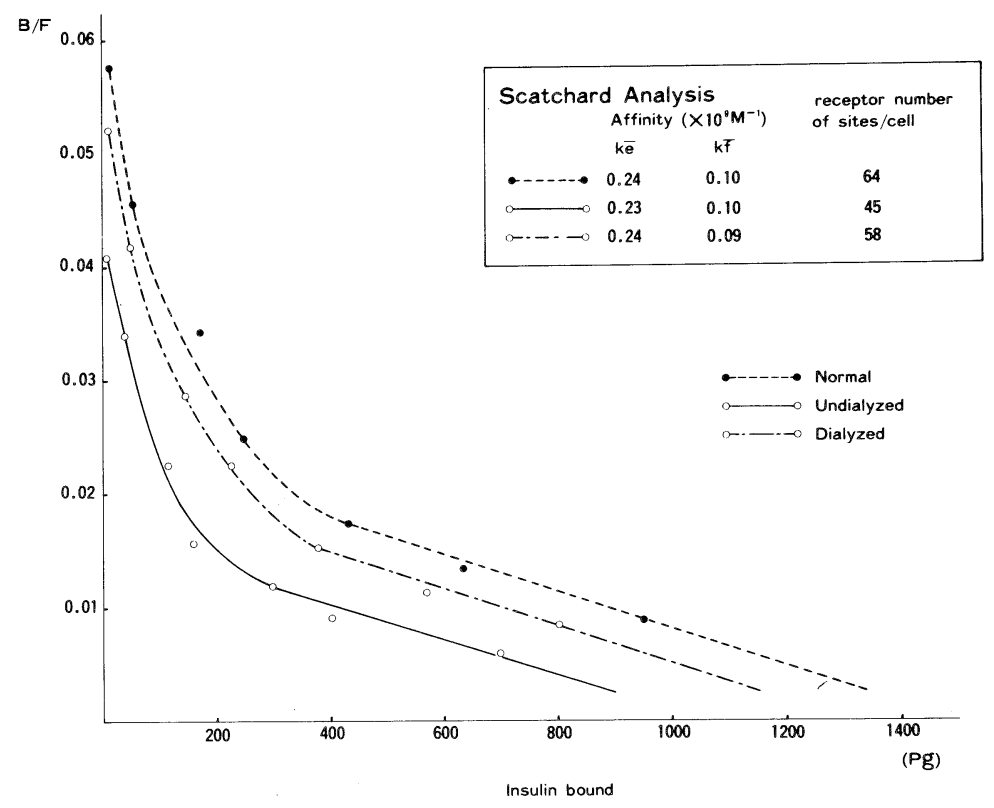

Figure 3 Scatchard plots of ${ }^{125}$ I-insulin specific binding to erythrocytes 


\begin{tabular}{c|c|c}
\hline & Undialyzed & Dialyzed \\
\hline Fasting IRI & $\mathrm{r}=-0.342$ & $\mathrm{r}=-0.381$ \\
$\sum$ IRI & $\mathrm{r}=-0.116$ & $\mathrm{r}=-0.272$ \\
$\mathrm{~K}-$ Value & $\mathrm{r}=0.277$ & $\mathrm{r}=0.542^{*}$ \\
\hline${ }^{*} \mathrm{p}<0.05$ & \\
Table $2 \quad$ Correlation coefficients between ${ }^{125} \mathrm{I}$ \\
-insulin specific binding and each \\
parameters
\end{tabular}

It is considered that although erythrocytes are not target cells for insulin action and differ from other human cells in that they lack nuclei and do not internalize hormones ${ }^{16}$, their insulin receptors parallel those in monocytes or adipocytes ${ }^{17,18)}$. On the other hand, it has been reported that the number of insulin receptors in erythrocytes decreases with their age and that reticulocytes are rich in insulin receptor numbers ${ }^{19,20)}$. The erythrocytes of uremic patients have a shorter life span than those of normal persons and are rich in reticulocytes $^{21)}$. Therefore, when we employ erythrocytes for insulin receptor assay, it is necessary to take into account the unique features of the erythrocyte insulin receptors.

Conclusion

10 undialyzed patients, 12 dialyzed patients with chronic renal failure and 6 normal persons were subjected to IV-GTT and their insulin receptors were examined.

1) In spite of a high $\Sigma I R I$ level, the $K$ value in the undialyzed group was significantly lower than that in the normal group.

2) The insulin receptor concentration in the undialyzed group was lower than that in the normal group.

3) No singnificant difference in $\mathrm{K}$ value or insulin receptor concentration was observed between the dialyzed and normal groups.

\section{References}

1) Hampers, G. L., Soeldner, J. S., Doak, P. B. \& Merrill, J. P. : Effect of chronic renal failure and hemodialysis on carbohydrate metabolism. J. Clin. Invest. 45:1719-1731, 1966.

2) Attman, P. \& Gustafson, A. : Lipid and carbohydrate metabolism in uremia. J. Clin. Invest. 9 : 285-291, 1979.

3) DeFronzo, R. A., Andres, R., Edgar, P. \& Walker, G. W. : Carbohydrate metabolism in uremia : a review. Medicine $52:$ 469, 1973.

4) Gambhir, K. K., Archer, J. A., Nerurkar, S. G., Cruz, L. A. \& Sanders, M. : Erythrocyte insulin receptors in chronic renal failure. Nephron $28: 4-10,1981$.

5) Hales, C. N. \& Randle, P. J. : Immunoassay of insulin with insulin antibody precipitate. Biochem. J. $88: 137$ $-146,1963$.

6) Lundbaek, K. : Intravenous glucose tolerance as a tool in definition and diagnosis of diabetes mellitus. Br. Med. J. $2: 1567,1962$.

7) Gambhir, K. K., Archer, J. A. \& Carter, L. : Insulin radioreceptor assay for human erythrocytes. Clin. Chem. $23: 1590-1595,1977$.

8) Hunter, W. M. \& Greenwood, F. C. : Preparation of iodine-131 labelled human growth hormones of high specific activity. Nature $194:$ 495-496, 1962.

9) Scatchard, G. : The attractions of proteins for small molecules and ions. Ann. N. Y. Acad. Sci. 51 : 660-672, 1949.

10) Spitz, I., Rubenstein, A. H., Bersohn, I., Lawrence, A. M. \& Kirsteins, L. : The effect of dialysis on the carbohydrate intolerance of chronic renal failure. Horm. Metab. Res. 2 : 86-93, 1970.

11) Kaneda, H. \& Mimura, N. : Effect of dialysis treatment on glucose metabolism in uremic patients. Tohoku. 
J. Exp. Med. 35 : 122-142, 1977.

12) Tchobroutsky, G., Rosselin, G., Assan, R. \& Derot, M. : Glucose intolerance in uremia. II. Plasma growth hormone and glucagon values. Diabetologia $5: 25-28,1969$.

13) Bech-Nielsen, H., Pendersen, O. \& Lindskov, H. O. : Normalization of the insulin sensitivity and cellular insulin binding during treatment of obese diabetics for one year. Acta Endocrinol. 90 : 103-106, 1979.

14) Olefsky, J. M. : Decreased insulin binding to adipocytes and circulating monocytes from obese persons. J. Clin. Invest. $57: 1154-1164,1976$.

15) Wigand, J. P. \& Blackard, W. G. : Down regulation of insulin receptors in obese man. Diabetes $28: 287-291$, 1979.

16) Marshall, S. \& Olefsky, J. M. : Effects of lysosomatropic agents on insulin interactions with adipocytes : evidence for a lysosomal pathway for insulin processing and degradation. J. Biol. Chem. 254 : 10153-10160, 1979.

17) Olefsky, J. M. \& Reaven, G. M. : Decreased insulin binding to lymphocytes from diabetic subjects. J. Clin. Invest. $54: 1323-1328,1974$.

18) Kobayashi, M., Harano, Y., Yasuda, H., Kosugi, K. \& Shigeta, Y. : Insulin receptors in non-obese diabetics. (Abstract), Diabetes $28: 393,1979$.

19) Thomopoulos, P., Berthellier, M. \& Laudat, M. : Loss of insulin receptors on maturation of reticulocytes. Biochem. Biophys. Res. Commun. 85 : 1460-1465, 1978.

20) Eng, J., Lee, L. \& Yalow, R. S. : Influence of the age of erythrocytes on their insulin receptors. Diabetes 29 : 164-166, 1980.

21) Shainkin, R., Giatt, Y. \& Berlyne, G. M. : The presence and toxicity of guanidinopropionic acid in uremia. Kidney Int. 7 : Suppl. 302-305, 1975. 